\title{
Kepastian Hukum Tentang Pendaftaran Persekutuan Firma Setelah Terbitnya Permenkumham Nomor 17 Tahun 2018
}

\author{
I Wayan Gede Eka Gunawan 1, I Ketut Sudantra ${ }^{2}$
}

1Fakultas Hukum Universitas Udayana, E-mail: amerthabhumisupplier@gmail.com. 2Fakultas Hukum Universitas Udayana, E-mail: ketut_sudantra@unud.ac.id.

\begin{tabular}{l} 
"Info Artikel" \\
\hline Masuk: 26 April 2021 \\
Diterima: 23 Juni 2021 \\
Terbit: 1 Juli 2021 \\
Keywords : \\
Companies; firm; fast \\
DOI: \\
10.24843/AC.2021.v06.i02.p13 \\
Corresponding Author: \\
Eka Gunawan IWayan Gede, \\
amerthabhumisupplier@gmail.com \\
Badan Hukum, Firma; Cepat. \\
\end{tabular}

\begin{abstract}
The purpose the reseach is determined of the background of issuance of Permenkumham Number 17 of 2018 and legal certainty of the mandatory fellowship registration firm after the issuance of Permenkumham No. 17/2018. The kind of research using legal normative research, with primier legal material, secondary and tertiory, from these legal materials can be drawn the conclusions by using descriptive analysis methods. The results showed that in order to meet the dynamics of society in the registration of $\mathrm{CV}$, firms and Private Company and registration of their deeds of establishment through an online system to make it faster, efficient and in one instant, the government issued Permenkumham No. 17/2018. But the issuance Permenkumham No. 17/2018 is different from Article 23 and Article 28 of the Indonesian Commercial Code regarding the registration of Firm business entities which must be registered at the Registrar's Office of the District Court where the Firm is located and then the deed must be announced in the News of the Republic of Indonesia. Because of the KUHD has a higher legal hierarchy than a Permen, the Permen cannot override the existing regulations, because by law all its obligations and regulations must still be considered to exist and apply. Permenkumham No. 17/2018 is not in line with the KUHD which is on the legal hierarchy, so it is necessary to conduct an examination at the Supreme Court, in order to obtain results regarding legal certainty from the Permenkumham.
\end{abstract}

\footnotetext{
Abstrak

Tujuan dari penelitian ini adalah untuk mengetahui tentang latar belakang diterbitkannya Permenkumham Nomor 17 Tahun 2018 dan kepastian hukum wajib daftar persekutuan firma setelah terbitnya Permenkumham No. 17/2018. Jenis penelitian dari penelitian ini adalah penelitian hukum normatif, dengan bahan hukum primier, sekunder dan tersier, dari bahan hukum tersebut dapat menarik kesimpulan dengan menggunakan metode analisa diskriptif. Adapun hasil penelitian memperlihatkan bahwa untuk memenuhi dinamika masyarakat dalam pendaftaran firma, $C V$ dan persekutuan terbatas, dimana Pendaftaran Akta Pendiriannya melalui online system agar lebih cepat, efisien dan dalam satu pintu instansi, maka pemerintah menerbitkan Permenkumham No. 17/2018. Tetapi terbitnya
} 
Permenkumham No.17/2018 terdapat perbedaan dengan Pasal 23 dan Pasal 28 Kitab Undang-Undang Hukum Dagang tentang pendaftaran badan usaha Firma yang mana wajib didaftarkan di Kepaniteraan Pengadilan Negeri tempat kedudukan firma tersebut dan kemudian aktanya wajib di umumkan dalam Berita Acara NKRI. Karena KUHD hirarki hukummyalebih tinggi dari Permen, sehingga Permen tidak dapat mengesampingkan peraturan yang ada diatasnya, karena demi hukum segala kewajiban dan peraturannya harus tetap dianggap ada dan berlaku. Permenkumham No. 17/2018 tidak selaras dengan KUHD yang berada pada hirarki hukum diatasnya, sehingga perlu dilakukan pengujian di Mahkamah Agung, agar memperoleh hasil tentang kepastian hukum dari Permenkumham tersebut.

\section{Pendahuluan}

Dalam pembangunan nasional salah satu dasar pembangunan yang di utamakan adalah pembangunan dalam sektor ekonomi secara merata dan kuat sebagai upaya dalam mewujudkan masyarakat yang makmur dan adil dalam aspek ekonomi, hal tersebut telah tertanam dalam Dasar Negara yaitu Undang-Undang Dasar Republik Indonesia. Bertumbuhnya perekonomian pada Negara terlihat dari meningkatnya pelaku ekonomi yang berkembang dan terus tumbuh dalam berbagai kegiatan bisnis. Dalam rangka menumbuhkan dan mengembangkan sektor ekonomi, dimana dalam kemajuan dunia ekonomi bukan hanya sebagai dasar atas banyaknya pelaku usaha dan barang-barang yang tersedia, tetapi didukung juga dengan pelayanan yang berintegritas atas dasar sistematis, efesien dan cepat.

Dalam menjalankan usahanya, pengusaha dapat memilih berbagai bentuk usaha sesuai dengan jenis usahanya dan besaran modal usahanya tersebut, pilihannya kepada jenis usaha yang berbadan hukum atau memilih lebih praktis dengan badan usaha yang tidak berbadan hukum. Dari berbagai jenis usaha yang tersedia, oleh para pengusaha baru banyak dipilih badan usaha firma. Firma adalah persekutuan (maatschap) yaitu kerjasama diantara orang yang berdasarkan persahabatan dan saling kenal atau persekutuan, bisa orang yang sama prosesinya atau teman dalam perdagangan. ${ }^{1}$ Firma merupakan perusahaan yang badan usahanya bukan berbentuk badan hukum, dimana kelebihan dari badan usaha ini adalah setiap anggotanya berwenang dan bertindak berdasasarkan atas nama dari badan hukum perusahaannya sendiri dengan berdasarkan tanggung jawab secara renteng.

Adapun kebanyakan pengusaha baru lebih memilih badan usaha Firma dengan didasari oleh beberapa alasan, yaitu meliputi adanya pembagian kewenangan dan kebijakan yang lebih porposional, dengan adanya pembagian kewajiban yang jelas untuk setiap struktur organisasi bidang usahanya, pemimpin perusahaan dalam menjalankan usahanya dapat memberikan kewenangan kepada seorang anggotanya untuk memimpin berdasarkan kualitas dan keahliannya sesuai dengan bidang skill

\footnotetext{
${ }^{1}$ Harahap. M.Y. (2011). HUKUM PERSEKUTUAN TERBATAS, EDISI I, CETAKAN 3. Jakarta: Sinar Grafika. h.l
} 
dan kelebihan masing-masing. Pendirian Persekutuan Firma dibuat berdasarkan akta notaris, sehingga dalam proses penambahan modal lebih mudah dipercaya oleh lembaga perkreditan dan investor, pembagian hasil berdasarkan jumlah modal yang disetor diawal sesuai dengan penanaman modalnya, tetapi semua penanam modal di persekutuan firma berhak aktif dalam mengelola dan menjalankan perusahaan. Terhadap beberapa alasan tersebut, menjadi alasan kuat kenapa banyak pelaku usaha baru lebih memilih persekutuan firma sebagai badan usahanya dari pada badan usaha lainnya.

Perkembangan dan kebutuhan tentang pendaftaran perusahaan, pendaftaran penggabungan atau pendaftaran pembubaran perusahaan yang semakin banyak dari tahun ke tahun, merupakan imbas dari semakin berjamurnya pelaku usaha yang bermunculan, memerlukan suatu sistematis pendaftaran yang berintegritas dalam satu pintu. Disamping pendaftaran sistematis, pendaftaran secara elektronik juga dibutuhkan oleh masyarakat. Pendaftaran secara sistematis dimana masyarakat dapat mendaftarkan usahanya dengan sistem online, yang berarti tidak lagi memerlukan banyak instansi dalam proses pendaftarannya, selesai dengan hanya satu instansi yang berkonsentrasi penuh terhadap semua pendaftaran perusahaan. Pada khususnya, pendaftaran secara elektronik ini dibuat untuk mengimbangi kemajuan teknologi, dimana teknologi dapat mempersingkat yang panjang dan dapat mempercepat yang lama dengan kerja yang simple, one klik dan berintegritas serta berkonektifitas, menjadikan lebih effisien dan mudah berdasar pada teori kepraktisan dalam prosesnya.

Bersumber dari beberapa permasalahan tersebut Pemerintah merumuskan peraturan yang dapat menjembati kebutuhan tersebut dan hal tersebut juga di dasari oleh Peraturan Pemerintah No. 24 Tahun 2018 tentang Pelayanan Perizinan Berusaha Terintegritas secara Elektronik dengan system single submission, sehingga pada tahun 2018 Pemerintah telah menerbitkan Peraturan Menteri Hukum dan Hak Asasi Manusia Nomor 17 Tahum 2018 (Selanjutnya disebut Permenkumham No. 17/2018) tentang Pendaftaran Firma, CV dan PT, ${ }^{2}$ sebagai bentuk dukungan pemerintah terhadap sektor ekonomi yang lebih dinamis, efesien dan lebih cepat dalam mendorong perkembangan ekonomi.

Pemerintah dalam wewenangnya sebagai pemangku jabatan memiliki tujuan memberikan pelayan perijinan berusaha terintegritas secara elektronik, dan sebagai peraturan yang berkorelasi terhadap pendaftaran Firma, CV serta Persekutuan Perdata menjadi lebih mudah dengan system elektronik, dimana Permen tersebut diperkuat dengan disempurnakan Pasal 2 pada Permenkumham tersebut, mengatur mengenai pendaftaran Firma, CV serta Persekutuan Perdata dimana Pendaftarannya Akta Pendiriannya melalui sistem administrasi badan-badan usaha ( Selanjutnya disebut $\mathrm{SABU})$, dimana sistem pendaftaran dari beberapa badan usaha mendaftar melalui online system yang diselenggarakan oleh Direktorat Jendral Administrasi Hukum Umum. Sistem pendaftaran elektronik ini sangat membantu dalam memenuhi kebutuhan pelaku usaha dalam mendaftarkan usahanya, tetapi permasalahan timbul

2 Sudarsa. D.C. (2020). KEPASTIAN HUKUM PENDAFTARAN PERSEKUTUAN KOMANDITER PADA SISTEM ADMINISTRASI BADAN USAHA. Acta Comitas: Jurnal Hukum Kenotariatan. 536-545. h. 537. DOI:10.24843/AC.2020.v05.i03.p09. 
terkait dengan polemik peraturan antara Kitab Undang-Undang Hukum Dagang dengan Permenkumham No. 17/2018 tentang pendaftaran Firma, terhadap pendaftaran dan prosesnya badan usahan mana didaftarkan pada Kepaniteraan Pengadilan Negeri tempat dan kedudukaannya sesuai dengan Kepaniteraan Pengadilan Negeri setempat dan aktanya wajib diumumkan pada bagian Berita NKRI.

Dari pembahasan latar belakang tersebut diatas, penulis memiliki ketertarikan terhadap topik tentang Persekutuan Firma, terutama setelah terbitnya Permenkunham No. 17/2018. Dari latar belakang tersebut, menarik untuk mengangkat judul “Kepastian Hukum Terhadap Pendaftaran Persekutuan Firma Setelah Terbitnya Permenkumham Manusia Nomor No. 17 Tahun 2018". Dari latarbelakang tersebut didapatkan 2 (dua) rumusan masalah tentang pendaftran Firma, yaitu Bagaimanakah ratio-legis terbitnya permenkumham nomor 17 tahun 2018? Dan Bagaimanakah kepastian hukum wajib daftar persekutuan firma setelah terbitnya permenkumham nomor 17 tahun 2018?

Secara umum penelitian ini mempunyai tujuan mengembangkan dan meningkatkan pengetahuan tentang keilmuan di bidang Kenotariatan dan memahami lebih seksama mengenai kepastian hukum dalam pendaftaran Persekutuan Firma dengan peraturan yang terbaru. Sesuai dengan rumusan masalah di atas penulisan jurnal bertujuan secara khusus untuk mengetahui kepastian hukum tentang pendaftaran Persekutuan Firma dengan berbagai peraturan yang mengaturnya. Sebelum penulis membuat jurnal ini, penulis terlebih dahulu melakukan penelusuran, terdapat Jurnal yang memiliki kemiripan dengan judul jurnal ini yaitu Jurnal Hengki Permadi yang berjudul "Pengaturan Mengenai Pendaftaran Firma pada Sistem Administrasi Badan Usaha" yang membahas tentang pendaftaran Persekutuan Firma pada sistem administrasi badan usaha, ${ }^{3}$ kemudian Jurnal Annurdi yang berjudul "Tanggung Jawab Sekutu Firma Atas Kepailitan" yang membahas tentang Persekutuan Firma tentang kepailitannya. ${ }^{4}$ Adapun perbedaan paling ketara adalah, penilitian ini lebih berfokus pada persekutuan firma, berbeda dengan penulisan lainnya yang hanya mengangkat garis besar dari polemik diterbitkannya Permenkunham No. 17/2018, sehingga penulisan ini dianggap perlu diterbitkan untuk memahami lebih jauh atas terbitnya Permenkunham No. 17/2018 terhadap firma.

\section{Metode Penelitian}

Tujuan penelitian ini untuk mendapatkan hasil dari berbagai sudut pandang peneliti dan menemukan pemecahan permasalahan hukum. Adapun tujuan penelitian adalah mendapatkan kebenaran secara sistematis, metodologis, kosistensi. Dari penelitian tersebut dianalisa dan dikonbtruksikan menjadi data yang dapat di olah dan dikumpulkan. ${ }^{5}$ Metode Penelitian dalam penelitian ini adalah penelitian hukum normatif karena penulis mengkaji peristiwa hukum atau fakta-fakta hukum

\footnotetext{
3 Permadi. I. M. H (2019). PENGATURAN MENGENAI PENDAFTARAN FIRMA PADA SISTEM ADMINISTRASI BADAN USAHA. Acta Comitas: Jurnal Hukum Kenotariatan. 475-483. $h$. 477. doi:10.24843/AC.2019.v04.i03.p12.

${ }^{4}$ Annurdi. A. (2017). TANGGUNG JAWAB SEKUTU FIRMA ATAS KEPAILITAN. Tanjungan

Law Jurnal. 14-25.

${ }^{5}$ Dirjosisworo. S. (2010). PENGANTARILMU HUKUM. PT. Raja Grafindo. Jakarta.h. 166.
} 
berdasarkan norma hukum yang ada, 6 Penelitian hukum ini adalah penelitian hukum yang memberikan penjelasan sistematis aturan yang mengatur satu kategori hukum tertentu, menganalisis hubungan antara peraturan menjelaskan daerah kesulitan dan mungkin memprediksi pembangunan masa depan. ${ }^{7}$ Penulisan ini menggunakan tiga bahan hukum, bahan hukum primier, bahan hukum sekunder dan bahan hukum tersier. Bahan hukum primer meliputi Undang-Undang, KUHD, Permenkumham dan PP, dan bahan hukum sekunder meliputi pendapat para ahli yang terkait dengan penulisan ini dan hasil penelitian yang dapat memberikan penjelasan lebih terperinci dalam penulisan ini, dan bahan tersier berupa esklipedia dan kamus-kamus hukum yang terkait. Pengumpulan bahan hukumnya menggunakan teknik pengumpulan bahan hukum kepustakaan dan peraturan yang terkait. Teknik analisis yang dipergunakan adalah teknik deskripsi, interprestasi dan argumentasi sehingga penulis dapat menarik kesimpulan.

\section{Hasil dan Pembahasan}

\subsection{Ratio-legis terbitnya Permenkumham No.17/2018}

Bahwa berdasarkan pertimbangan terbitnya Peraturan Pemerintah Nomor 24 Tahun 2018 yang bertujuan dalam mempermudah masyarakat dalam mendaftarkan perusahaannya dengan Pelayanan Perizinan Berusaha Terintegrasi Secara Electronik (Online Single Submission). Dimana perizinan usaha yang sebelumnya berada pada Pengadilan Negeri setempat, tetapi sejak di terbitkannya permenkumham tersebut sehingga akan berpindah menjadi wewenang permenkumham RI, dan selain itu layanan pendaftarannya digunakan secara online, tidak lagi memakai system manual atau offline.

Adapun alasan terbitnya permenkumham 17/2018 adalah dalam menghadapi dan mengikuti dinamika perkembangan ekonomi global dan internasional, dibutuhkan peraturan yang cepat dan effisien dalam penanaman modal terhadap investor, sehingga menimbulkan iklim ekonomi yang sehat. Terbitnya permenkumham 17/2018 adalah untuk menggenjot pertumbuhan enonomi skala nasional dan diharapkan permenkumham tersebut mempermudah segala urusan menjadi online sistem, sehingga dapat meningkatkan penanaman modal terutama investor internasional dan tentunya berfokus kepada investor local dan pengusaha domestik. Lebih condongnya berbagai peraturan tehadap investor dengan berbagai kemudahan mendaftarkan perusahaan milik investor dalam negeri, perlu dibentuk suatu system satu pintu yang mempermudah pengusaha-pengusaha baru dalam rangka memperkokoh ekonomi dalam negeri, baik dari sektor mikro sampai skala makro terhadap investasi jangka pendek maupun panjang.

Untuk mempercepat dan mewujudkan Pelayanan Perizinan Berusaha Terintegritas Secara Elektronikal, yang mana memiliki dasar yaitu Peraturan Pemerintah nomor 24 tahun 2018 mulai Pasal 15 sampai Pasal 17 diperlukan penetapan beberapa aturan dalam mempercepat perekonomian Negara, dengan mengubah pendaftaran

${ }^{6}$ Barus. Z. (2003). ANALISIS FILOSOFIS TENTANG PETA KONSEPTUAL PENELITIAN HUKUM NORMATIF DAN PENELITIAN HUKUM SOSIOLOGIS. Jurnal Dinamika Hukum 13(2). 307-318. h. 310 doi: 10.20884/1.jdh.2013.13.2.212.

${ }^{7}$ Marzuki. P.M. (2011). PENELITIAN HUKUM CETAKAN II. Kencana Prenada Media. Jakarta. $h$. 32. 
perusahaan menjadi online sistem, pemerintah melalui Kementerian Hukum dan HAM, menerbitkan permenkumham tersebut dengan tujuan penguatan sektor investasi dalam negeri menjadi lebih kuat, mudah dan cepat, sehingga investor tertarik untuk menanamkan modalnya. Perkembangan dan konsistensi dari peraturan yang telah disiapkan diharapkan dapat mempermudah pengusaha dan investor dalam mendaftarkan badan usahanya. Hal ini sesuai dengan salah satu tujuan hukum yaitu kemanfaatan hukum. Menurut Jeremi Bentham, tujuan hukum adalah memberi kemanfaatan dan kebahagiaan sebanyak-banyaknya kepada warga masyarakat yang didasari oleh falsafah sosial yang mengungkapkan bahwa setiap warga Negara mendambakan kebahagiaan, dan hukum merupakan salah satu alatnya. ${ }^{8}$

Tujuan hukum itu dapat bermanfaat bagi masyarakat, hukum harusnya memberikan manfaat bagi mereka yang diaturnya dan dapat menimbulkan kebahagiaan yang besar bagi masyarakat. Segala bentuk peraturan yang berlaku adalah bertujuan mengatur dan membentuk masyarakat sebagaimana menjadi alat untuk terciptanya ketertiban dan keteraturan kepada masyarakat yang hidup sesuai dengan norma hukum. Pada dasarnya peraturan tersebut dapat mendatangkan manfaat dan kegunaan terhadap hukum adalah bertujuan menciptakan ketertiban dan ketentraman dalam kehidupan bermasyarakat.

Dinamika pembangunan Indonesia dengan perkembangan masyarakat dipicu dengan kemajuan ilmu pengetahuan dan teknologi yang saat ini telah memasuki industri global 4.0, yang ditandai dengan perubahan besar dalam bidang perdagangan dari dulunya manual menjadi elektronik melalui online sistem. Perubahan sistem yang terjadi dan terus berkembang mengharuskan perubahan-perubahan aturan yang dapat mendukung sector investasi sehingga tidak tertinggal atas perkembangan global. Pembangunan hukum yang dilakukan oleh pemerintah harus dinamis mengikuti tuntutan global dalam menghadapi kontradiksi terhadap dunia industri, khususnya bidang bisnis.

Revolusi industri global 4.0 memberikan perkembangan pesat dalam interaksi, konektivitas dan tidak adanya batas antar manusia, mesin dan sumber daya lainnya. Hal tersebut mendasari perubahan bagaimana cara orang hidup, cara mereka berinteraksi dan bagaimana cara mereka berhubungan satu sama lainnya. Dinamika pembangunan yang dilandasi kemajuan global tersebut sangat dekat pengaruhnya terhadap tatanan hukum, sehingga harus ditanggapi secara kritis, cermat dan inovatif terhadap pembangunan hukum kedepannya.

Pada awal tahun 2018, pemerintah membuat strategi nasional terutama dalam menghadapi industri global 4.0, yang salah satunya adalah memfokuskan inovasi pada sektor industri elektronik. Hal tersebut selaras dengan diterbitkannya Permenkumham 17/2018 yang mana berfokus terhadap pendaftaran perusahaan yang dilakukan serba elektronik melalui sistem online. Pemerintah telah mempersiapkan hal tersebut dengan tujuan mempermudah para pelaku usaha dalam menghadapi ero global 4.0 tersebut, sehingga terjadi suatu hubungan yang dinamis antara masyarakat,

\footnotetext{
8 Darmodihardjo. D. (2011). FILSAFAT HUKUM: EDISI LENGKAP (DARI KLASIK SAMPAI POSTMODERENISME). Jogyakarta: Universitas Adma Jaya Jogyakarta. h. 159.
} 
perkembangan global dengan peraturan yang sesuai dengan kebutuhan dan ilmu pengetahuan dan teknologi.

\subsection{Kepastian Hukum Wajib Daftar Persekutuan Firma Setelah Terbitnya Permenkumham Nomor 17 Tahun 2018}

Sebelum memastikan kepastian hukum tentang pendaftaran persekutuan firma setelah terbitnya Permenkumham 17/2018 tersebut sebagai dasar hukum atas pendaftaran online system persekutuan firma, maka terlebih dahulu perlu dikaji beberapa perbedaan dengan KUHD yang sebelumnya dijadikan dasar utama dalam pendaftaran persekutuan firma.

Perbedaan yang paling terlihat mengenai pendaftaran persekutuan firma dari sudut pandang Permenkumham 17/2018 dengan KUHD adalah dibagian pendafatarannya, pembubaran yang mana pada pasal 2 (dua) Permenkumham No. 17 Tahun 2018 menyatakan bahwa pendafatarannya, pembubaran firma dilakukan melalui Sistem Administrasi Badan Usaha (SABU) dengan system onlinenya, sedangkan pada pasal 23 KUHD mengenai pendaftaran persekutuan firma wajib didaftarkan pada Pengadilan Negeri setempat. Adanya tumpang tindih dan ketidaksesuaian norma diantara Pasal 3 Permenkumham 17/2018 dengan Pasal 23 KUHD menimbulkan adanya suatu ketidakpastian hokum. ${ }^{9}$ Sehingga diperlukan kepastian hukumnya, dengan adanya kepastian hukum dalam hal pendirian badan usaha yang diberikan kepada para penanam modal dalam melakukan usahanya ini mampu memberikan jaminan keuntungan secara ekonomis bagi para pihak. ${ }^{10}$

Apabila mengacu dari teori kemanfaatan bahwa pendaftaran atau pembubaran persekutuan firma diatur dalam Pasal 2 Permenkumham 17/2018 dianggap lebih effisien, cepat dan mudah karena dilakukan dengan system online dimana dapat dilakukan dimana saja tanpa harus mendaftar secara manual di Pengadilan Negeri sesuai dengan pasal 23 KUHD. Karena sebelum Permenkumham tersebut diterbitkan, pendaftaran dan pembubaran persekutuan firma dilakukan di Pengadilan Negeri dimana kedudukan persekutuan firma tersebut berada, karena berdasarkan Aturan Peralisan pada Pasal 2 UUD 1945, KUHD masih berlaku mengikat dan mengatur peraturannya dan masih berlaku sampai saat ini, sehingga harus tetap dijalankan aturan-aturannya.

Tentang kepastian hukum mengenai kedudukan tentang pendaftaran Persekutuan Firma setelah terbitnya Permenkumham tersebut diatur dalam Permen 12/2011 dan menyebutkan bahwa Pembentukkan Peraturan Perundang-Undangan tentang kepastian hukum yang mengacu kepada jo. Adagium lex superiori derograt lex impreriori, maka pendaftaran persekutuan firma tetap didaftarkan pada Pengadilan Negeri

\footnotetext{
9 Utami.P.D.Y (2020). PENGATURAN PENDAFTARAN BADAN USAHA BUKAN BADAN HUKUMMELALUISISTEM ADMINISTRASIBADANUSAHA. Pengaturan Pendaftaran Badan JKH Universitas Pendidikan Ganesha. 6(1). 1-19.h. 14. doi: 10.23887/jkh.v6i1.23432.

${ }^{10}$ Lasakar. M. (2019). KEABSAHAN PERATURAN MENTERI HUKUM DAN HAK ASASI MANUSIA NOMOR 17 TAHUN 2018 TENTANG PENDAFTARAN PERSEKUTUAN KOMANDITER, PERSEKUTUAN FIRMA DAN PERSEKUTUAN PERDATA. Jurnal Media Hukum Dan Peradilan. 193-213. doi:index.php/jmhp/artic...
} 
setempat, meskipun Pengadilan Negeri termasuk dalam rumpun kekuasaan yudikatif, tetapi secara normatif kedudukan KUHD lebih tinggi dari Permenkumham. Hal ini mengacu pada heirarki tentang klasifikasi aturan Undang-Undang di Indonesia bahwa KUHD masih berlaku di Indonesia pada saat ini.

KUHD merupakan Undang-Undang yang ada di atas herarki hukum Permenkumham $17 / 2018$, apabila terdapat perbedaan diantaranya, peraturan-peraturan yang terdapat pada Permenkumham 17/2018 tidak dapat mengesampingkan KUHD, karena demi hukum segala kewajiban atau peraturan dalam KUHD harus tetap dianggap ada dan berlaku. Teori perjenjangan norma menyatakan bahwa dari norma yang paling bawah berlaku sampai norma yang paling atas, sampai dengan norma-norma yang tidak dapat ditelusuri disebut dengan grundnorm atau dasar hukumnya. Pada dasarnya norma yang lebih tinggi harus di ikuti oleh norma-norma yang ada dibawahnya dan tidak boleh bertentangan. ${ }^{11}$ KUHD peraturannya adalah setingkat Undang-Undang, sehingga pada hakikat dan herarkinya Permenkumham 17/2018 selaras dengan KUHD. Tetapi jika terdapat perbedaan dan pertentangan, peraturan yang didahulukan adalah adalah peraturan paling atas atau mencari peraturan lain yang tidak bertentangan dengan aturan setingkat atau diatas heirarkinya. Dilihat dari herarkinya, aturan yang semestinya dipakai adalah KUHD karena merupakan peraturan tertinggi pada peraturan itu.

Berdasarkan Undang-Undang 12/2011 menyatakan bahwa Permen atau Peraturan Perundang-undangan tetap diakui keberadaannya, selama diperintahkan oleh peraturan yang ada di atasnya dan memiliki kekuatan hukum tetap, sesuai dengan Pasal 8 Ayat (1) dengan syarat-syarat bahwa peraturan tersebut merupakan perintah dari peraturan yang ada diatas hirarkinya dan dirumuskan memakai dasar kewenangan, baik kewenangan atribusi dan kewenangan delegasi dalam pembentukannya, serta merupakan implementasi dari kemanfaatan hukum.

Delegated Legislation adalah peraturan yang dibuat dari Undang-Undang yang ada diatasnya atau pedelegasian sebagai bagian dari Peraturan Undang-Undang tersebut. Sedangkan peraturan yang dibuat tanpa adanya delegasi dari hirarki hukum yang lebih tinggi disebut dengan aturan kebijakan, peraturan ini dibuat oleh pemerintah administrasi Negara dan berlaku secara mengatur dan mengikat masyarakat umum, tetapi bukan merupakan Peraturan perundang-undangan. ${ }^{12}$ Karena bukan merupakan Peraturan Undang-Undang, permen yang timbul karena sebuah kebijakan tidak dapat di uji pada Mahkamah Agung, tetapi berdasarkan ketentuan Pasal 8 Ayat (2) UndangUndang Nomor 12 Tahun 2011 menyatakan bahwa permen yang diterbitkan sebelum Undang-Undang Nomor 12 Tahun 2011 tetap dianggap berlaku sepanjang tidak dicabut dan dibatalkan.

Apabila Permenkumham No. 17/2018 dianggap tidak selaras dengan Undang-Undang yang ada diatas hirarkinya, hal tersebut dapat diuji oleh Mahkamah Agung, sehingga dapat diperoleh hasil dari pengujian tersebut, apakah dibatalkan, dirubah atau dapat dibuatkan menjadi Undang-Undang pengganti. Diterbitkannya Permenkumham No. 17/2018 dapat disimpulkan peraturan tersebut dibentuk dengan tujuan membantu

\footnotetext{
11 Soeprapto. M. F. I. (2010). ILMU PERUNDANG-UNDANGAN. Yogyakarta: Kanisius. h. 41. ${ }^{12}$ Efendi. A., Poernomo. F. (2017). HUKUM ADMINISTRASI. Jakarta:Sinar Grafika.h. 48.
} 
kewenangan dan kebijakan urusan pemerintah tertentu dalam sebuah kementerian dan bukan merupakan perintah dari Peraturan Undang-Undang yang lebih tinggi hirarkinya. Peraturan yang di atur dalam Permenkumham No. 17/2018 yang bertentangan dengan peraturan KUHD, diperlukan pengkajian ulang dan berlanjut supaya tidak terjadi tumpang tindih aturan. Dengan kata lain, pemerintah sebagai pemangku kebijakan membuat Undang-Undang baru yang setara dengan KUHD, sehingga KUHD dianggap telah tergantikan dengan Undang-Undang yang baru tersebut, sehingga segala sesuatu yang teratur dalam dalam Permenkumham No. 17/2018 akan tetap berlaku, begitu sebaliknya dengan KUHD apabila tergantikan.

Pendaftaran Firma sesuai dalam Permenkumham No. 17/2018 membuat terjadinya dualism peraturan yang dianggap tumpang tindih terhadap peraturan yang sudah ada dengan peraturan yang baru. Pada sisi dimana pendaftaran harus dengan system online yang dianggap lebih effisien tetapi terbentur dengan hirarki Undang-Undang diatasnya, sehingga ditakutkan dimana Permenkumham ini dibuat untuk membantu masyarakat malah menimbulkan polemik dan menghambat iklim investasi di Negara ini. Dengan selisih peraturan antara Permenkumham dengan KUHD menunjukkan tidak selaras antara peraturan antara tingkatan heirarki peraturan peundangundangan, juga dapat menjadi kebingungan bagi masyarakat antara pendaftaran di pengadilan negeri dan melalui SABU. Kepastian hukum dalam hal ini adalah tujuan Undang-Undang tidak dapat tercapai karena dualisme keberadaan peraturan yang tidak selaras. Karena seberadaraan Permenkumham 17/2018 ada karena tujuan dari administrasi Negara terhadap fungsi hukum tersebut, yaitu membantu masyarakat untuk mencapai tujuan Negara.

\section{Kesimpulan}

Diterbitkannya Permenkumham No. 17/2018 bertujuan untuk mempercepat dan mempermudah proses pendaftaran persekutuan melalui Sistem Administrasi Badan Usaha, karena berintegritas dengan sitem elektronik, tetapi Permenkumham No. 17/2018 ini terbentur dengan Pasal 23 KUHD yang secara hirarki ada diatasnya. Hal ini terkait dengan pendaftaran badan usaha Firma wajib didaftarkan di Kepaniteraan Pengadilan Negeri tempat dimana kedudukan Firma tersebut dan wajib diumumkan akta mana dalam Berita NKRI, dari sudut kepastian hukum secara hierarki kedudukan KUHD lebih tinggi dari Permenkumham No. 17/2018 dan sesuai kedudukan dan kepastian hukumnya KUHD harus lebih didahulukan dari pada peraturan yang ada dibawahnya, meskipun peraturan lain melaksakan segala hal menjadi lebih praktis, cepat dan efesien. Konsekwensi hukum lebih lanjutnya adalah Permenkumham No. 17/2018 tidak dapat mengesampingkan KUHD, sehingga dengan demikian semua kewajiban atau peraturan yang terdapat di KUHD demi hukum harus tetap dianggap berlaku.

\section{Daftar Pustaka / Daftar Referensi}

\section{$\underline{\text { Buku-Buku }}$}


Darmodihardjo. D. (2011). FILSAFAT HUKUM: EDISI LENGKAP (DARI KLASIK SAMPAI POSTMODERENISME). Jogyakarta: Universitas Adma Jaya Jogyakarta.

Dirjosisworo. S. (2010). PENGANTAR ILMU HUKUM. PT. Raja Grafindo. Jakarta.

Kansil. C. S. T. (2005). HUKUM PERUSAHAAN INDONESIA (ASPEK HUKUM DALAM EKONOMI) BAGIAN I. Pradnya Paramita, Jakarta.

Fajar. N. D. M., Achmad. Y. (2010). DUALISME PENELITIAN HUKUM: NORMATIF \& IMPIRIS. Yogyakarta: Pustaka Pelajar.

Marzuki. P. M. (2011). PENELITIAN HUKUM CETAKAN II. Kencana Prenada Media.

Harahap. S. H. M. Y. (2011). HUKUM PERSEROAN TERBATAS. Sinar Grafika, Jakarta.

Soeprapto. M. F. I. (2010). ILMU PERUNDANG-UNDANGAN. Yogyakarta: Kanisius

\section{Jurnal}

Andiyanto. K., Mujiburohman. D. A., \& Budhiawan. H. (2021). PENERAPAN PENDAFTARAN HAK TANGGUNGAN TERINTEGRASI SECARA ELEKTRONIK DI KANTOR PERTANAHAN KOTA PEKANBARU. Acta Comitas: Jurnal Hukum Kenotariatan. 198-210. doi: 10.24843/AC.2021.v06.i01.p17.

Annurdi. A. (2017). TANGGUNG JAWAB SEKUTU FIRMA ATAS KEPAILITAN. Tanjungan Law Jurnal. 14-25.

Barus. Z. (2003). ANALISIS FILOSOFIS TENTANG PETA KONSEPTUAL PENELITIAN HUKUM NORMATIF DAN PENELITIAN HUKUM SOSIOLOGIS. Jurnal Dinamika Hukum 13(2). 307-318. doi: 10.20884/1.jdh.2013.13.2.212.

Dharnayanti. N. M. P., Usfunan. Y. \& Sarjana, I. M. (2007). HUBUNGAN HUKUM PERUSAHAAN INDUK BERBENTUK PERSEROAN TERBATAS DENGAN ANAK PERUSAHAAN BERBENTUK PERSEKUTUAN COMANDITER. Acta Comitas, 66-74.

Diana. P. V. P., Mertha. I. K. \& Artha, I. G. (2015). PERTANGGUNG JAWABAN NOTARIS DALAM PEMBUATAN AKTA BERDASARKAN PEMALSUAN SURAT OLEH PARA PIHAK. Acta Comitas, 161-172. 
Diatmika. I. G. A. O., Atmadja. I. D. G., \& Utari, N. K. S. (2014). PERLINDUNGAN HUKUM TERHADAP JABATAN NOTARIS BERKAITAN DENGAN ADANYA DUGAAN MALPRAKTEK DALAM PROSES PEMBUATAN AKTA OTENTIK. Acta Comitas, 150-160.

Lasakar. M. (2019). KEABSAHAN PERATURAN MENTERI HUKUM DAN HAK ASASI MANUSIA NOMOR 17 TAHUN 2018 TENTANG PENDAFTARAN PERSEKUTUAN KOMANDITER, PERSEKUTUAN FIRMA DAN PERSEKUTUAN PERDATA. Jurnal Media Hukum Dan Peradilan. 193-213. doi:index.php/jmhp/artic...

Permadi. I. M. H (2019). PENGATURAN MENGENAI PENDAFTARAN FIRMA PADA SISTEM ADMINISTRASI BADAN USAHA. Acta Comitas: Jurnal Hukum Kenotariatan. 475-483. doi: 10.24843/AC.2019.v04.i03.p12.

Prabawa. I. G. N. W. (2020). PERAN NOTARIS DALAM PENDIRIAN KOPERASI SETELAH DIBERLAKUKANNYA ONLINE SINGLE SUBMISSION. Acta Comitas: Jurnal Hukum Kenotariatan. 411-422. doi: 10.24843/AC.2020.v05.i02.p17.

Rahmadi. I. T., Fahamsyah. E., \& Pratama. R. H. (2020). KEPASTIAN HUKUM PENDIRIAN PERSEKUTUAN COMANDITER (CV) DI INDONESIA MENURUT PERMENKUMHAM NO. 17 TAHUN 2018. Jurnal panorama Hukum. 169-181. doi: 10.21067/jph.v5i2.4553.

Ratnawati. A. (2015). PERANAN NOTARIS UNTUK PEMBUATAN AKTA PENDIRIAN (CV) DALAM MEWUJUDKAN KEPASTIAN HUKUM. Jurnal Repertorium, Volume II No. 2. 154-160.

Sudarsa. D.C. (2020). KEPASTIAN HUKUM PENDAFTARAN PERSEKUTUAN KOMANDITER PADA SISTEM ADMINISTRASI BADAN USAHA. Acta Comitas: Jurnal Hukum Kenotariatan. 536-545. doi:10.24843/AC.2020.v05.i03.p09.

Suryawan. I. G. A. Y. (2020). TANGGUNG JAWAB NOTARIS MENGGUNAKAN LAYANAN LITJEN AHU ONLINE DALAM HAL PENDAFTARAN AKTA DAN PENGESAHAN BADAN HUKUM. Acta Comitas: Jurnal Hukum Kenotariatan. 492-503. doi: 10.24843/AC.2020.v05.i03.p05.

Utami. P.D.Y (2020). PENGATURAN PENDAFTARAN BADAN USAHA BUKAN BADAN HUKUM MELALUI SISTEM ADMINISTRASI BADAN USAHA. Pengaturan Pendaftaran Badan JKH Universitas Pendidikan Ganesha. 6(1). 1-19. doi: 10.23887/jkh.v6i1.23432.

\section{Peraturan Peundang-Undangan}


Kitab Undang-Undang Hukum Perdata (KUHPerdata)

Kitab Undang-Undang Hukum Dagang (KUHD)

Peraturan Pemerintah Nomor 24 Tahun 2018 tentang Pelayanan Perizinan Berusaha Terintegritas Secara Elektronik

Peraturan Menteri Hukum dan Hak Asasi Manusia Republik Indonesia Nomor 17 Tahun 2018 tentang Pendaftaran Persekutuan Komanditer, Persekutuan Firma dan Persekutuan Perdata. 